\title{
エッセイ
}

\section{進化について考える 一種族維持という言葉について一}

\author{
早 川 洋 一 - 小 林 牧 人 (国際基督教大学・理学科) \\ hyouichi@nt.icu.ac.jp
}

\section{1. まえがき}

内分泌学において内分泌系の機能的意義や ホルモンの定義が研究の発展とともに変わる ように、生物の進化がどのようなしくみで起 こってきたか、その考え方にも変遷があった ことは周知のことと思わ机る。

筆者 $(\mathrm{MK})$ が中学校の理科の授業で習った ホルモンの定義は、ビタミンとともに微量生 体調節物質の範疇に入り、生体内でつくれる ものがホルモン、生体内でつくれないものが ビタミンであったように記憶している。その 後、大学の講義では、内分泌系は神経系と共 に生体内情報伝達系として扱われ、さらに大 学院のころから免疫系をあわせて生体調節系 と呼ばれるようになった。一方、ホルモン は、当初内分泌椂式によって放出されるもの と定義されていたが、傍分泌や自己分泌によ つて放出されるものもホルモンと呼ばれるよ うになった。こうした内分泌学における考え の変化はフォローしているつもりではあった が、今日のように細分化の進んだ生物学にお いて、少し自分の専門分野から離れた分野の 発展をフォローするのはなかなか困難となっ てきた。

このような中で最近、異分野の研究者と の議論を重ねるうちに生物の進化についての 筆者 (MK) の理解が out-of-dateだったので はないかという思いを持つようになった。そ うした反省の意味も含めて、行動生態学の 分野にも属し、進化に詳しいもう一人の筆者 (YH) とともに本学会のニュースにおいて本 稿を書くに至った。

生物学は進化生物学と機能生物学とに大別
できるが、機能生物学においてある動物のも つメカニズムの機能を考えるとき、種族維持 のためと解釈する場合が多い。また生殖の意 義＝種族維持といつた表現もよくなされる。 実際、大学生向けの生物学の本や高校生向け の参考書には、今なお種族維持が生物学にお ける公理のように記されている。しかし、生 物学者必携の岩波書店刊「生物学辞典」をみ ても種族、種族維持という言葉はない。実 は、進化生物学においては「種族維持」「種 の保存」といった考元方は、20年以上前に否 定されているのであった。ところが「種族維 持」という言葉は、日本の機能生物学者の間 でよく使われているように感じる(筆者 $\mathrm{MK}$ も最近まで使っていた)。このことと関連が あるかどうかはわからないが、日本の生物学 者の進化に対する理解は、ちょっと遅れてい る、というコメントが著名な国際科学雑誌で 話題になったそうである。

ぞのような経緯で日本の生物学者がこのよ うなコメントを受けるようになったかは別と して、比較内分泌学会という「進化」を看板 に揭げた分野に属する者として、ここではも う一度、進化について考えてみたい。

\section{2.「『比較』生物学」と進化}

生物学において「比較」が語頭につく学問・ 研究分野は本学会を始めとして数多く存在す る。岩波書店の「生物学辞典」をみると、比 較形態学、比較解剖学、比較発生学.......など が項目としてあげられ、それらを総じて「比 較生物学」と記されている。現在、「比較」が 意味するところは各分野によって様々かと思 
われるが、歴史的にみると比較生物学は「… ‥進化論の誕生の土台となり、また進化論 の確立により推進された」(生物学辞典)とあ る。その意を踏むと比較生物学の中で「進化」 の視点は今なお重要な位置を占めると考えら れる。

一方、近年、人々の環境への意識が高ま り、メディアにおいても生物多様性や環境保 全の話題を目にしない日がないほどだ。それ は、長い生命の歴史を踏まえた地球規模の視 点で取り組まれている問題であり、そこでも 進化の正しい理解が不可欠になっている ${ }^{1)}$ 。

生物進化を考えるとき、ダーウィンの提 唱に由来する自然選択の役割を認めることは 現代の進化生物学では共通の了解になってい る2。しかし、先に触れたように、進化を自 然選択とは元来無縁の種族維持 (種の利益) の観点でとらえるといつた誤解もいまなおみ られる。本稿では、「比較」の意の源である 科学的な進化について概説しょう(なお、本 稿の内容は進化の大筋に触れたものであるこ とをご留意いただきたい)。

\section{3.「進化」とは？}

国語辞典には「進化」の意の中に機能や構 造の「上昇」や「改善」というニュアンスが記 されている。これを生物に当てはめれば、「高 等化」複雑化」に置き換えられるかも知れな いが、生物の進化にはこうしたニュアンス を含まない。確かに動物は魚類の中から両 生類の特徴を持った種が生じ、その中からは 虫類の特徵を持った種が生じ……という進化 の歴史を経ている。結果として、起源種や起 源的形質を多く残す種に比べて体の構造が複 雑化する場合が多い。しかし、へビの足のよ うに骨格の一部が痕跡的に残り、外部形態的 には消失したのも進化の産物である。進化は 高等化を意味しないとはこういうことで、方 向性や目的などなく、結果的に今ある生き

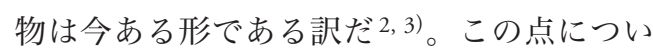
てNHK教育の「科学大好き土曜塾」という番 組の中でJT生命誌研究館の中村桂子先生が
「(現存する微生物からほ乳類を指しながら) 私たちは生命誕生から多様な進化の過程を経 て38億年後の今を生きる38億歳の生き物た ち」と表されていたのが大変印象深い。言い 換えると体のつくりが比較的単純な現世の微 生物も 38 億年の進化を経た生き物なのだ。

では、生物の進化とはどういうことだろ うか? 端的に言えば、「生物が時間と共に 様々に変化すること」であり ${ }^{4)}$ 、そのなかで 自然選択説は進化のしくみを考える上での中 核となっている4,5)。

\section{4. 進化のプロセス}

自然選択によると、進化はどのように説明 されるのだろうか？ここでは「害虫と殺虫 剂の関係」を取り上げてみよう。殺虫剤は自 然界には存在しないが、これは米国の大学で 使われる名高い生物学の教科書 ${ }^{6}$ でも用例さ れるほど自然選択の過程を端的に説明できる ので、その点をご容赦願いたい。曰く「ある 地域には人畜に有害な害虫が生息し、人々は 殺虫剤を散布してその害虫の駆除を計った。 初めのうちは、その殺虫剤は害虫退治に効果 的だったが、次第に効かなくなっていった… …」これは、害虫が殺虫剂への耐性を持つ ようになったから、と説明するのは難くない だろう。ただ「耐性を持つようになった」と いうと、最初は弱かった個体が殺虫剤を被 るたびに次第に強くなって (=形質を獲得)、 その性質が子供にも伝わったと捉えられるか も知れない。しかし、これは間違いである。 害虫の中には殺虫剂の散布前から耐性を持つ 個体が少なからず存在し、耐性を持たない多 くの個体が死んでもそれらは生き残つた。そ して、自分らと同じく殺虫剤への耐性を持っ た子孫を残し、それが次世代以降にも続き、 やがて殺虫剤に対して強い個体の集団ができ たのだ (ここでは他地域からの移入は考慮に 入れていない)。もちろん、殺虫剤散布前に 耐性を持つ個体が全くいなければ、すべて死 滅していただろう(図1)。

耐性を持つ個体と持たない個体が殺虫剤 
1

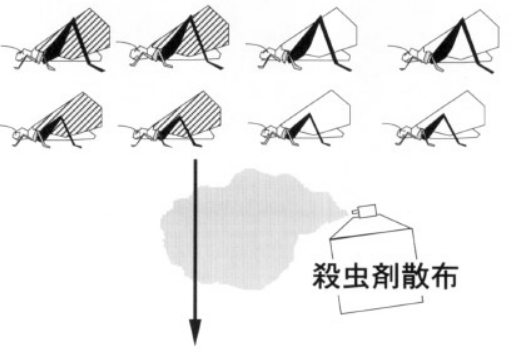

2

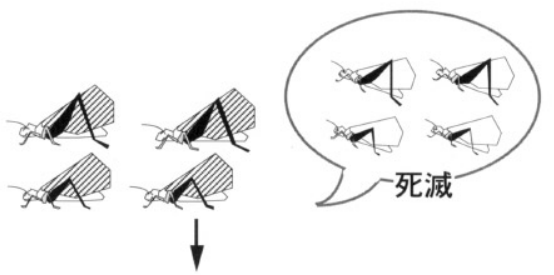

3
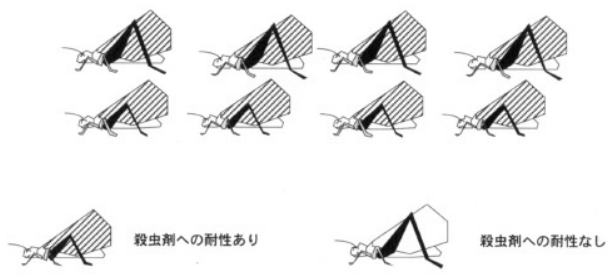

図 1 害虫と殺虫剂散布

1。当初、害虫には殺虫剤への耐性を持つ個体と 持たない個体が混在していた。

2. 殺虫剤が散布されると、それへの耐性を持た ない個体は死滅するが、耐性を持つ個体は生 き残る。

3. やがて殺虫剤への耐性を持つ個体が増えてい く。図中では殺虫剤への耐性を羽根の模様で 区別した。なお、両者の中にも脚の後脚に大 小があることに注意。

の散布前から混在することは、「個体間の変 異」の存在を意味する。また、殺虫剤の散布 は害虫にとって大きな環境の変化となる。次 世代以降の多くの子孫が殺虫剤に耐性を持っ ているのは、その形質が「遺伝」したからだ。 つまり、「害虫と殺虫剤の関係」は、「次世代 に遺伝する性質の中に殺虫剤への耐性があ り、その有無には個体間で差がある。そして 耐性を持った個体だけが殺虫剂散布 (環境変 化）があっても生き残り（選択）、その性質を 継承(遺伝)した多くの子孫が残された」とい うことであり、これは「ある環境の変化に対 して適応できるか否かには個体間の変異があ り、生き残った個体 (選択された個体)の形
質が次世代に遺伝しながら子孫が増えて、新 たな集団ができる」と言い換えられる。これ が自然選択のプロセスである（ちなみにアニ メーション『ポケモン』のキャラクターがと きどきみせる “進化” は同一個体における変 化であるから、生物学的には「進化」ではな く強いて言うなら「変態」に相当するかも知 れない)。

さて、教科書での話は以上で終わりであ るが、ここでは次のようなエピソードを加え てみよう。「A市には隣接した B市とC市があ り、どちらの市も A市と同様に害虫に悩まさ れていた。B市は $\mathrm{A}$ 市が殺虫剤散布による害 虫駆除を行うとき賛同したがC市はお金が なく参加をとりやめた。B市での結果は $\mathrm{A}$ 市 と同様で、一旦、害虫は減ったかに思えた が、数年後増加に転じてしまった。A市はB 市に新たな手段による害虫駆除を持ちかけた が、B市は殺虫剤散布でお金を使い果たして しまったために参加しなかった。そこでA市 は害虫を好んで食べる動物の移入による害虫 駆除を単独で試みた。はじめのうち害虫は減 少したため今回の方法が成功したかにみえた が、数年後にはやはり害虫の数が増し、結果 的に失敗に終わってしまった。このとき、A 市の害虫をよくみると、B市やC市のものよ り後ろ脚が平均的に大きく、小さな脚の個 体より動きが素早くなっていた。さらにA市 の害虫はC市のものとは生殖不能になって いた(なお、A市群、B市群およびC市群の 間で害虫の移動・交配がほとんどないと仮定 している）」。整理すると最終的に害虫はA市 群、B市群およびC市群の三群が存在するこ とになり、このうち環境の変化を何も受けな かったのがC市群で、B市群は殺虫剂散布の、 $\mathrm{A}$ 市群は殺虫剂散布と移入動物の侵入という 環境変化をそれぞれ経ている。

以上のプロセスを自然選択から説明する と、B市群やC市群のものより A市群で後ろ 脚が大きいのは、元々脚の大きさには個体間 の差があり、大きい足を持つ個体が動物から 素早く逃避するのに有利だったために生き残 
つたと説明できる。さらに、長い年月の間に 生殖に関わる部位にも変化が生じ、A市群と C市群とは交配できなくなってしまったの だ。これら一連の話は例え話であり、時間的 スケールは現実的なものとは言えないにして も、生殖可能かどうかのレベルを種を分ける 線引きとすると、A市群は何も変化していな いC市群とは別種となり、種分化の 1 プロセ スにあたる。実は魚類から両生類が出現した 大進化の過程なども、基本的には同様のプロ セスに依る。

\section{5. 進化における「種族維持」の間違い}

このように、自然選択では個体間の変異が 重要である。どのような生物が、いつ、いか なる環境の変化に遭遇するかは予測がつかな い。しがたってどのような性質の個体間の変 異が適応的かは時々の環境や状況による。つ まり、自然選択には目的や方向性がない。結 果的に進化の根本は、ある環境を生き残るこ とができた個体がどれだけ多くの子孫を残せ るかにかかっている。すなわち、進化とは個 体の生存と利益 (どれだけ自分の子孫を残せ るかということ）が基本となって生じるもの なのである2〜10)。

しかしながら、生物進化の説明に「種の利 益(=種族維持)」の考えが用いられることが ある。すなわち、ある性質が進化するかは 「種の利益」になるか否かで決まるというも ので、自然選択とは相反するものだ。この考 え方では、特定の個体やある地域の個体群の 生存が有利になって生き残ることはない。あ る地域で環境変化とそれに伴う生物の変化 が起きると、そことは全く環境が違う別の場 所にすむ個体にも生じ、一斉に種全体に行 き渡ることが前提となる。先の害虫の例でい うと、各市で別個に生じた環境変化が種の存 続を脅かすものであれば、各市の害虫で起き る変化はその都度離れた市の全ての個体に起 きる。逆に、ある市の生物にとって生命に深 刻な状況が起きても、種の存続に影響しない のであればその種の生き物には何の変化もな
い。つまり、「種の利益 (=種族維持)」とは、 生物の変化はあくまで種全体が保たれるか否 かにかかっている、という考え方である。し かし、実際には種全体に及ぶ危機のレベルが どのようもので、生物が変化するかしないか の指示がどうのように種全体に伝わるのかに ついての合理的な説明は全くない2)。

種族維持が生物の根本的な性質であるとい う考えを支持する議論に、同じ種内では他の 個体を殺すことはあり得ない、という話があ つた7,8,10)。他個体を殺すことは種族維持を 危うくするから進化しないというのがその 理由である。その反対に動物が集団自殺する のは種内の個体数が増えるのを防ぎ、種の保 存に役立つから進化したのだという話もあっ た2,7,10)。しかし、同種内での他個体殺しは ライオンやサルの仲間では正常状態でみら れる現象であり、オスが自分の子孫を残す上 で重要な行動であることが明らかとなってい $3^{7,8)}$ 。一方、集団自殺は、実は自殺ではな く、それまで生息していた場所にいては生 殖の可能性が低い個体 (例えばなわばりを持 てなかったり巣穴を作れないなどの理由によ る）が新たな場所への移動を試みた際に危険 に遭遇し、命を落としただけであることが分 かっている10)。

さらに、種族維持という考えに基づくと、 動物の各個体の行動は帰属する種に有益に なるよう振る舞うものと解釈される。言い 換えると利他的なものである。このような場 合、集団(他個体) への利益の方が自己の利 益より優先されることになる。しかし、これ はある集団が外部との接触が全くなく、完全 に閉鎖した状況であれば成り立つかも知れな いが、環境が変化し、それによって生息環境 も容易に変化する地球上ではあり得ない。も し、利他的行動のみをする集団の中に自分 の利益のみを追求する集団からの移入があ ったり、利他集団内に利已的な性質の突然変 異体が出現したりしたらどうなるだろうか？ 利他的な個体は急速に消滅してしまうだろ う9)。 
確かに、動物には利他的に振る舞う場合が 多々みられる。社会性動物のアリでは働きア リ（全てメスである）は自己の繁殖を犠牲に して自分の妹である働きアリの世話をして母 親である女王に奉仕する。自分の子供の世話 をするのは理解できても、妹の世話となると 理解し難く、自己犠牲の最たるものとみえる かも知れない。しかし、子孫を残すことを自 分 (と共通)の遺伝子を次世代に受け渡すこ とと捉えると話が全く違つてくる。つまり、 アリではオスが半数性でメスが二倍性である ため、働きアリは血縁度 (=共通の遺伝子の 多さ: 平たく言えば血のつながり)が $1 / 2$ の自分の子供を残すより $3 / 4$ の妹の世話を しているのである。つまり、自分が持つ遺伝 子と同じ遺伝子をより多く共有する子孫を残 す方法が採られているのである7〜9)。

また、魚や鳥では群れ行動が多々みられ、 多くの時間を集団で過ごす動物がいる。その 大きな理由の一つは各個体が別個にいるより 集団化した方が各個体の生存に有利な点が上 げられる。その方が外敵を見つけやすかった り、逃避しやすかったりするのだ ${ }^{8)}$ 。さらに は、受精という子孫を残す上で直接的な出来 事に際しても、オスが他人の邪魔をしてメス を得ようとしたり横取りする動物もいれば、 前のオスとの交尾でメス胎内にある精子を 掻き出してから自分の精子を入れる動物もい たり、異個体由来の精子が受精を巡って争っ たり (精子間競争)、果ては受精をしない精 子(異型精子) を、受精する精子と並行して 作ってそれらの受精をサポートする動物もい る ${ }^{8,11)}$ 。こうした現象は種族維持という考え からは科学的に合理性を持った説明ができな い(なお、以上に記した様々な動物の例は、 本稿の引用文献を参照されたい)。

\section{6. おわりに}

このように、ダーウィンが考えた自然選択 は種族維持や種の利益とは合致しない。しか し、種族維持の視点は根強く残っている。そ れは生物における種と人間社会における種
族を同一視して、互恵的社会 ${ }^{12)} の 人$ 間を基 準にして動物の生活観、行動規範あるいは社 会を捉えるからかもしれない2,4,7)。進化は 進歩でなく目的がないというのも、人間の生 活観を基準にすれば違和感があるかも知れな (3)。

かつては保全生態学の分野においても種族 維持や種の保存といつた考えは使われていた ようだが、現在では生物多様性の観点から生 態系全体を保全するという観点に変化してい る1)。したがって、科学的にみると、「種族 維持」という言葉は、少なくとも科学的な進 化を基盤とする生物学では使われない方向に あるのだろう。進化生物学、行動生態学の分 野においては、進化が研究の中心であるが、 率直なところ比較生物学の分野においては、 得られた研究成果をもとに進化についても考 えてみようか、といった感じがする。しかし 比較生物学といつた分野において、いつもで なくてもたまには、比較 (進化) そのものに ついて考えることが重要であると思われる。

本稿をまとめるに当たり、中京大学教養 部・桑村哲生教授ならびに山形大学理学部・ 渡邊明彦助教授よりご助言を頂いた。ここに 感謝の意を表する。

\section{文 献}

1 ) 前田琢 (2001) 樋口広芳編、保全生物学。 東京、東京大学出版会。pp71-102。

2 ) 粕谷英一 (1992) 柴谷篤弘・長野敬 養老孟司編、講座「進化 $7 」$ 生態学か らみた進化。東京、東京大学出版会。 pp39-78。

3 ）グールド・S. J. (2000) 干し草の中の恐 竜 (上・下)。東京、早川書房。

4 ) 長谷川真理子 (1999) 進化とはなんだろ うか。東京、岩波書店。

5 ) 速水格 (1988) 東京大学公開講座「進 化」。東京、東京大学出版会。pp1-24。

6 ) Campbell, N.A. and Reece, J. B. (2002). Biology, sixth ed. Benjamin Cummings, San Francisco, CA, USA. 
7 ) 桑村哲生 (2001) 生命の意味。東京、裳 華房。

8 ）クレブスJ. R. \&デイビスN. B. (1991) 行 動生態学。東京、蒼樹書房。

9 ) 長谷川真理子 (1996) 雄と雌の数をめぐる 不思議。東京、NTT出版。
10）河田雅圭（1990）はじめての進化論。東 京、講談社。

11）早川洋一 (2003) 日本比較内分泌学会二ュ ース。109、34-37.

12）トリバース R。生物の社会進化。東京、 産業図書。 